\title{
Racial and Ethnic Sentencing Differentials in the Federal Criminal Justice System Online Appendix
}

\author{
Brendon McConnell Imran Rasul
}

January 18, 2018 


\section{Table A1: Sentencing Guideline Cells}

(months imprisonment)

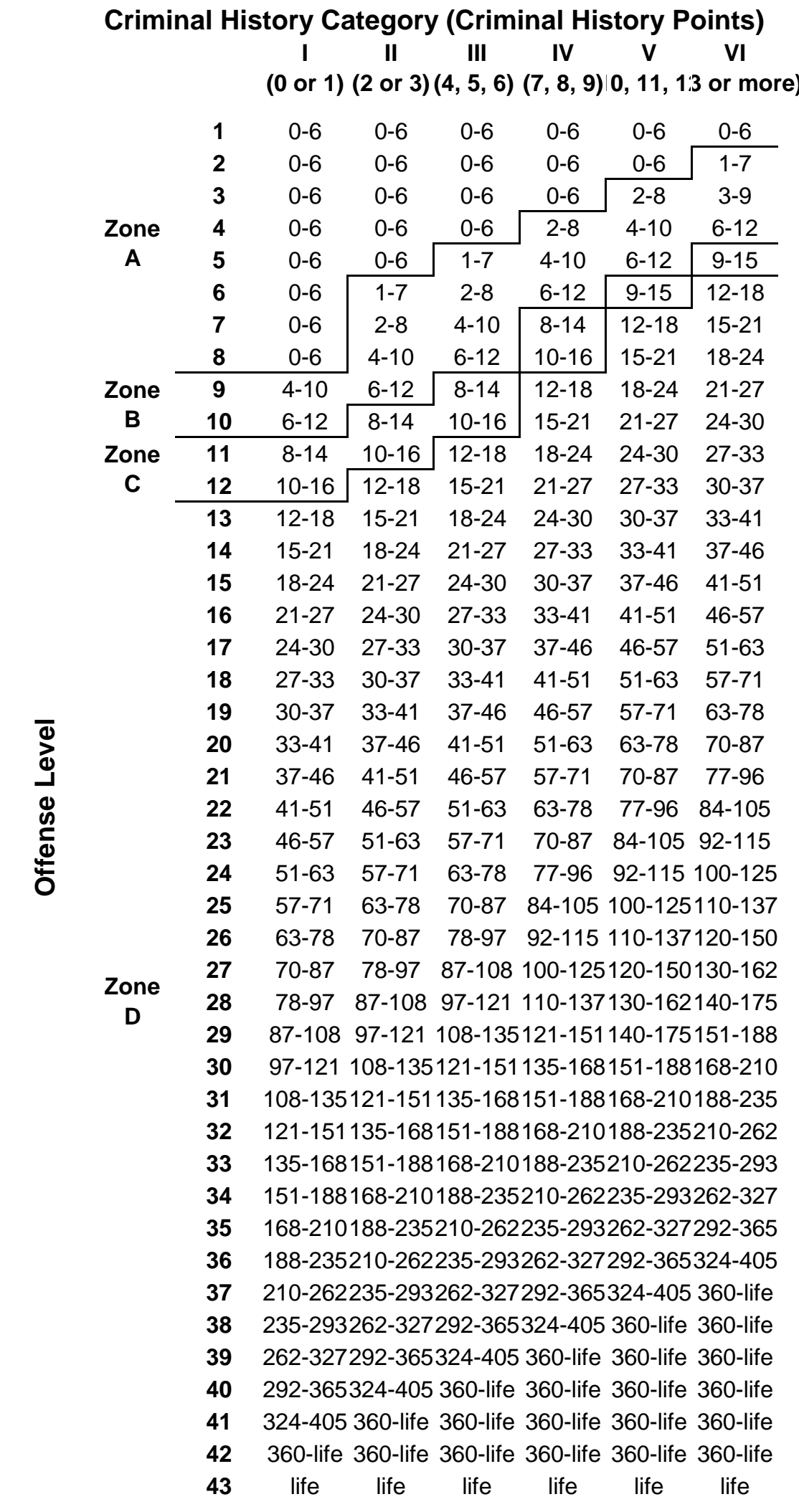

Source: Chapter 5, 2001 Federal Sentencing Guidelines Manual [http://www.ussc.gov/sites/default/files/pdf/guidelines-manual/2001/manual/CHAP5.pdf ] 


\section{Table A2: Descriptives, by Ethnicity and Gender}

Means, standard deviations in parentheses.

Men

White Black Hispanic

Sample Size
Number Dependents

Age
$73,786 \quad 60,653 \quad 101,045$

$\begin{array}{lll}1.15 & 1.68 & 1.85\end{array}$

(1.80)

32.1

(9.22)
Women

White Black Hispanic

\begin{tabular}{ccc}
\hline 15,686 & 12,076 & 10,928 \\
\hline 1.11 & 1.54 & 1.76 \\
$(1.30)$ & $(1.54)$ & $(1.64)$ \\
36.6 & 33.2 & 33.0 \\
$(11.3)$ & $(9.94)$ & $(10.1)$
\end{tabular}

Marital Status:

\begin{tabular}{|c|c|c|c|c|c|c|}
\hline Single & 0.337 & 0.536 & 0.328 & 0.275 & 0.504 & 0.335 \\
\hline Married & 0.353 & 0.205 & 0.344 & 0.341 & 0.189 & 0.245 \\
\hline Other & 0.289 & 0.237 & 0.244 & 0.363 & 0.275 & 0.355 \\
\hline \multicolumn{7}{|l|}{ Education Level: } \\
\hline Less than High School & 0.260 & 0.404 & 0.635 & 0.237 & 0.295 & 0.533 \\
\hline High School Graduate & 0.377 & 0.365 & 0.165 & 0.409 & 0.338 & 0.239 \\
\hline Some College & 0.226 & 0.184 & 0.072 & 0.267 & 0.296 & 0.130 \\
\hline College Graduate & 0.125 & 0.038 & 0.019 & 0.073 & 0.056 & 0.031 \\
\hline \multicolumn{7}{|l|}{ Defense Counsel: } \\
\hline Privately Retained & 0.169 & 0.080 & 0.072 & 0.128 & 0.071 & 0.103 \\
\hline Court Appointed & 0.173 & 0.176 & 0.298 & 0.202 & 0.197 & 0.266 \\
\hline Federal Public Defender & 0.122 & 0.141 & 0.262 & 0.124 & 0.150 & 0.199 \\
\hline Other & 0.007 & 0.006 & 0.002 & 0.010 & 0.013 & 0.004 \\
\hline Criminal History Score & $\begin{array}{c}2.19 \\
(1.64)\end{array}$ & $\begin{array}{c}3.05 \\
(1.84)\end{array}$ & $\begin{array}{c}2.40 \\
(1.67)\end{array}$ & $\begin{array}{c}1.57 \\
(1.16)\end{array}$ & $\begin{array}{c}1.71 \\
(1.30)\end{array}$ & $\begin{array}{c}1.41 \\
(1.00)\end{array}$ \\
\hline Offense Severity & $\begin{array}{c}17.9 \\
(8.45)\end{array}$ & $\begin{array}{c}22.2 \\
(9.43)\end{array}$ & $\begin{array}{c}18.4 \\
(8.05)\end{array}$ & $\begin{array}{c}14.6 \\
(7.91)\end{array}$ & $\begin{array}{c}14.5 \\
(8.39)\end{array}$ & $\begin{array}{c}16.4 \\
(7.67)\end{array}$ \\
\hline
\end{tabular}

Notes: The full sample refers to all Federal cases that come up for sentencing from 10/1/1998 to 09/30/2003. For each gender we show the descriptive statistic for each race/ethnicity. Standard errors are shown in parentheses for continuous variables. For marital status, the "Other" category incorporates cohabiting, divorced, widowed and separated. For defense counsel the "Other" category incorporates defendant represented self, waived rights to counsel and other arrangements for counsel. 